\title{
顎口腔領域への転移性腫瘍についての臨床的検討
}

\author{
矢内雄 $太^{1,2)} \cdot$ 大山順子 ${ }^{1)} \cdot$ 窪田泰孝 ${ }^{1,2)}$ \\ 杉浦 剛 ${ }^{3}$ ) 清島 保 ${ }^{4)}$ ·白砂 兼 光 $^{1)}$
}

\section{Clinical study of metastatic tumors to the jaws and oral cavity}

\author{
YANAI Yuta $^{1,2)} \cdot$ OHYAMA Yukiko $^{1)} \cdot$ KUBOTA Yasutaka $^{1,2)}$ \\ SUGIURA Tsuyoshi $^{3)} \cdot$ KIYOSHIMA Tamotsu $^{4}{ }^{\text {) }} \cdot$ SHIRASUNA Kanemitsu ${ }^{1}{ }^{\text {) }}$
}

\begin{abstract}
Metastatic tumors to the jaws and oral cavity account for $1 \%$ to $2 \%$ of all oral cancers. We report the clinical characteristics of the tumors in 11 patients among a total of 697 cases of oral cancer treated in the Section of Oral and Maxillofacial Surgery, Kyushu University Hospital from 1985 through 2010. At the first visit, 9 of the 11 patients had a history of primary tumor, while the primary cancer sites were uncertain in the other 2 patients. Six of the 9 patients had recurrence or metastasis of their primary tumors, and in the other 3 patients tumor spread was controlled. The tumor was detected in mandibular and maxillary bones in 9 patients and 2 patients, respectively. Ten of the 11 patients had metastases in the molar region. Five of the 8 patients with mandibular molar metastasis had symptoms of hypoesthesia in the lower lips and chin. Seven of the 11 cases were adenocarcinoma. Regardless of treatment such as surgical resection, radiotherapy, or chemotherapy, alone or combined, all patients had poor outcomes, and the average survival time from the first visit was 3.2 months.
\end{abstract}

Key words: metastatic tumor (転移性腫瘍), jaws and oral cavity (顎口腔領域), clinical characteristics (臨床的特徵), prognosis (予後)

緒

他臟器原発の悪性腫瘍の顎口腔領域への遠隔転移は，口 腔癌の $1 \sim 2 \%$ 程度と報告されている ${ }^{1,2)}$. 本邦に打ける 報告の多くは少数例の症例報告 ${ }^{2,3)}$ で, その臨床的な特徴 をまとめた報告は少ない. そのため疾患の認知度も低く ${ }^{4)}$, 診断や治療に苦慮する場合も多い。今回私たちは, 当科で 経験した顎口腔領域への転移性腫瘍 11 例について臨床的 に検討したので報告する。

1) 九州大学大学院茵学研究院口腔靧顔面病態学講座口腔頭 顔面外科学分野

(主任：森 悦秀教授)

2) 国家公務員共済組合連合会佐世保共済病院茵科口腔外科 （主任：篞田泰孝部長）

3) 鹿児島大学大学院医茵学総合研究科先進治療科学専攻䫈 顔面機能再建学講座顎顔面疾患制御学分野

(主任：杉浦 剛教授)

4) 九州大学大学院茵学研究院口腔顎顔面病態学講座口腔病 理学分野

（主任：清島 保教授)

${ }^{1)}$ Section of Oral and Maxillofacial Surgery, Division of Maxillofacial Diagnostic and Surgical Science, Faculty of Dental Sciences, Kyushu University (Chief: Prof. MORI Yoshihide)

\section{対象と方法}

1985 年から 2010 年に九州大学病院顔面口腔外科を受診 し, 病理組織学的に口腔悪性腫瘍と診断された 697 例中, 他臓器から顎口腔領域への転移性腫瘍と診断された 11 例 (1.6\%) を対象とした。診断基準はClausen $5^{5)}$ および Zegarelli $5^{6)}$ の方法に従った. すなわち，1) 臨床的, 組 織学的に原発腫瘍の存在が証明されていること，2）原発 腫瘍と転移病巣が組織学的に類似していること，3）過去

${ }^{2)}$ Department of Oral and Maxillofacial Surgery, Sasebo Kyosai Hospital (Chief: Dr. KUBOTA Yasutaka)

${ }^{3)}$ Maxillofacial Diagnostic and Surgical Sciences, Department of Oral and Maxillofacial Rehabilitation, Course of Advanced Therapeutics, Kagoshima University Graduate School of Medical and Dental Sciences (Chief: Prof. SUGIURA Tsuyoshi)

4) Section of Oral Pathology, Division of Maxillofacial Diagnostic and Surgical Science, Faculty of Dental Sciences, Kyushu University (Chief: Prof. KIYOSHIMA Tamotsu)

受付日：2015 年 6 月 10 日

採択日：2016 年 1 月 26 日 
に転移病巣部位に腫瘍が存在していないこと，4）隣接す る臓器からの直接的な腫瘍浸潤がないこと, を満たす症例 を転移性腫瘍とした。生検を行っていない症例, 悪性リン パ腫等の血液系腫瘍の症例，頸部リンパ節転移のみで顎口 腔領域に病変のない症例は検討から除外した。

これらの症例の原発腫瘍の部位と治療，顎口腔転移巣の 臨床所見と病理組織学的所見, 診断に至った経緯やその後 の治療および予後について調査した.

骨転移と軟組織転移の鑑別は片岡ら 7 ) の分類を参考と した。すなわち, 単純 X 線あるいは CT で顎骨内の囊胞性 透過像や中心が顎骨内にあるびまん性 X 線透過像を示す症 例を骨転移とした。

なお, 本研究は九州大学病院倫理委員会の承認を得て行 われた。

\section{結果}

\section{1. 年齢および性別}

11 例の年齢は 40 歳から 80 歳 (平均年齢 $65.6 \pm 10.8$ 歳) で, 男性 6 例 (平均年齢 $70.7 \pm 5.0$ 歳), 女性 5 例 (平均年 歯 $59.4 \pm 13.1$ 歳) であった。平均年齢は男女間で有意差は なかった。

\section{2. 原発腫瘍の特徵（表 1)}

原発腫瘍の部位は肺が 3 例，胃，子宮がそれぞれ 2 例， 大腸，甲状腺，前立腺，心臓がそれぞれ 1 例であった。初 診時に他藏器の悪性腫瘍の既往が明らかであったものは 9 例（症例 1 9）で, 2例（症例 10,11）は顎口腔領域の転移 巣が先に発見され，その後原発腫瘍が特定された。症例 1 〜 6 6 例は原発巣の制御が十分でなく, 当科初診時にす でに他臓器への転移を認めていた。症例 $7 〜 9$ の 3 例では 原発腫瘍は制御されていたが，顎口腔転移巣の発見後さら に他藏器への転移が認められた。頸部リンパ節転移を認め たのは症例 11 のみで, 両側顎下リンパ節への転移を認め た. 原発腫痬の診断時点から顎口腔転移までの期間は, 1 か 月から 6 か月が 5 例, 1 年以上が 4 例であった.

\section{3 . 顎口腔転移巣の特徵（表 1 )}

転移部位は上顎 1 例，下顎 9 例で，1例（症例 5) は上下 顎であった。顎関節部へ転移した 1 例（症例 7) ${ }^{8}$ ）を除いた 全例が四菊部であった。軟組織への転移は認めなかった。

初診時の臨床症状は，9例 $(81.8 \%)$ が㐘肉の腫瘤で，そ のうち 8 例は比較的境界明瞭, 表面平滑な腫瘤であった。 腫瘤の長径は平均 $32 \pm 9.7 \mathrm{~mm}$ で, 6 例が $30 \mathrm{~mm}$ 以上であ った。長径が $45 \mathrm{~mm}$ 以上であった 3 例の腫瘤は分葉状を呈 していた。潰瘍形成を認めたのは 1 例のみで, 原因は対合 歯との接触であった。
腫瘤を形成した 9 例では, 全例で単純 X 線または CT で 顎骨内を中心とする骨吸収像を認めた。吸収様式は，びま ん性が 4 例, 圧迫性と虫食い状がそれぞれ 2 例, 囊胞性が 1 例であった。腫瘤形成が認められなかった 2 例では骨吸 収を認めず，1例で骨硬化像を認めた。

下唇とオトガイ部の知覚鈍麻は，下顎への転移例 9 例中 5 例 $(55.6 \%)$ に認められ, 初診時に腫瘤形成を認めなかっ た 2 例の主症状であった。

その他の症状として, 㐘の動摇が 4 例 $(36.4 \%)$ に, 患部 の自発痛が 3 例 $(27.3 \%)$ に認められ, 顎関節部への転移 例では開口障害が認められた ${ }^{8)}$.

病理組織学的診断の結果, 覀性腫瘍の既往のなかった 2 例で他藏器からの転移が示唆され, その後の検索によって 原発巣の診断に至った。症例 11 は診断に苦慮したもので, 問題提起のため詳細を後述する.

\section{4．治療と予後 (表 2)}

顎口腔領域の病変に対しては, 治療による Quality of life （QOL）の維持, 改善が期待できる 9 例では減量手術を含 む腫瘤の切除または放射線治療を施行した。切除を行っ た 3 例は， 2 か月間の生存期間中に口腔機能を損なう腫瘍 の増大は認めなかった。放射線治療を行った 4 例の治療 効果は, Stable Disease が 3 例 (症例 $5 \sim 7$ ), Progressive Disease が 1 例（症例 2) であった。原発腫瘍および顎口腔 以外の転移巣に対しては放射線治療や化学療法が行われた (表 1). 当科初診後の生存期間は最長で 6 か月, 7 例が 3 か月以下で, 平均 3.2 か月であった.

症例 $11: 59$ 歳, 女性.

\section{症 例 提 示}

主 訴: 下唇の知覚鈍麻.

現病歴：2007 年 12 月中旬, 右側下唇・オトガイ部打よ び右側下顎長側歯肉の違和感を自覚し, 症状が持続するた め近在柬科医院からの紹介で 12 月下旬に当科を受診した.

既往歴：糖尿病, 高血圧症, 骨粗鬆症, 子宮筋腫. 初診時現症 :

全身所見; 全身状態良好. 特記事項なし.

口腔外所見; 右側オトガイ神経領域の知覚鈍麻を認めた. 口腔内所見；異常所見なし．

画像所見：デンタルおよびパノラマ $\mathrm{X}$ 線検査で異常所見 を認めなかった。

処置および経過 1 : 非定型知覚異常の臨床診断で 2 週間 ごとの経過観察となっていたが, 2 週間後は著変なく 1 か 月後の再来予定日には体調不良のため来院されなかった. その後右側下顎歯肉に腫瘤を自覚し, 頭部, 頸部にも腫瘤 が出現したため, 2008 年 2 月中旬に再来した. 
表 1 原発腫瘍と顎口腔転移巣の特徵

\begin{tabular}{|c|c|c|c|c|c|c|c|c|c|c|c|}
\hline \multirow[b]{2}{*}{ 症例 } & \multirow[b]{2}{*}{ 年齢 } & \multirow[b]{2}{*}{ 性別 } & \multicolumn{5}{|c|}{ 原発腫瘍 } & \multicolumn{4}{|c|}{ 顎口腔転移巣 } \\
\hline & & & 原発巣 & 病理診断 & $\begin{array}{c}\text { 原発巣の } \\
\text { 治療 }\end{array}$ & $\begin{array}{c}\text { 他臟器への } \\
\text { 転移 }\end{array}$ & $\begin{array}{c}\text { 他の転移巣 } \\
\text { の治療 }\end{array}$ & $\begin{array}{c}\text { 転移まで } \\
\text { の期間 }\end{array}$ & 転移部位 & 骨吸収様式 & 知覚鈍麻 \\
\hline 1 & 70 & 男 & 肺 & 大細胞癌 & $\mathrm{C}$ & 肝 & $\mathrm{C}$ & 3 か月 & 下顎骨 & びまん性 & なし \\
\hline 2 & 66 & 男 & 肺 & 腺癌 & $\mathrm{R}$ & 骨 & $\mathrm{R}$ & 1 年 & 下顎骨 & びまん性 & あり \\
\hline 3 & 67 & 男 & 肺 & 小細胞癌 & $\mathrm{C}$ & 脳 & $\mathrm{C}$ & 1 か月 & 下顎骨 & びまん性 & なし \\
\hline 4 & 57 & 女 & 甲状腺 & 腺癌 & $\mathrm{O}, \mathrm{R}$ & 肺 & $\mathrm{R}$ & 5 か月 & 下顎骨 & 虫食い状 & あり \\
\hline 5 & 76 & 女 & 心臟 & 偽肉腫様癌 & $\mathrm{R}$ & 骨, 肺, 肝 & $\mathrm{R}$ & 3 か月 & 上下顎骨 & 圧迫性 & なし \\
\hline 6 & 40 & 女 & 子宮 & 扁平上皮癌 & $\mathrm{O}, \mathrm{R}$ & 脳 & $\mathrm{R}$ & 2 年 & 上顎骨 & 圧迫性 & なし \\
\hline 78$)$ & 65 & 女 & 子宮 & 腺癌 & $\mathrm{O}, \mathrm{C}, \mathrm{R}$ & 前縦隔 & $\mathrm{C}$ & 6 か月 & 下顎骨 & 虫食い状 & なし \\
\hline 8 & 70 & 男 & 前立腺 & 腺癌 & $\mathrm{O}$ & 骨 & $\mathrm{C}, \mathrm{R}$ & 6 年 & 下顎骨 & なし（骨硬化） & あり \\
\hline 9 & 71 & 男 & 胃 & 腺癌 & $\mathrm{O}, \mathrm{R}$ & 骨, 肺, 肝 & $\mathrm{R}$ & 4 年 & 下顎骨 & 囊胞性 & なし \\
\hline 10 & 80 & 男 & 胃 & 腺癌 & - & 骨, 肺 & なし & - & 下顎骨 & びまん性 & あり \\
\hline 11 & 59 & 女 & 大腸 & 腺癌 & - & $\begin{array}{l}\text { 骨, 肺, 肝, } \\
\text { 副腎, 皮膚 }\end{array}$ & なし & - & 下顎骨 & なし & あり \\
\hline
\end{tabular}

$\mathrm{C}$ ：化学療法 $\mathrm{R}$ ：放射線療法 $\mathrm{O}$ : 手術療法

表 2 顎口腔転移巣の治療と予後

\begin{tabular}{cccc}
\hline 症例 & 治療 & 治療効果 & 生存期間 \\
\hline 1 & $\mathrm{O}$ (減量) & 腫痬増大なし & 2 か月 \\
2 & $\mathrm{R}$ & $\mathrm{PD}$ & 6 か月 \\
3 & $\mathrm{O}$ & 腫痬増大なし & 2 か月 \\
4 & 生検のみ & - & 1 か月 \\
5 & $\mathrm{R}$ & $\mathrm{SD}$ & 2 か月 \\
6 & $\mathrm{R}$ & $\mathrm{SD}$ & 不明 \\
$78)$ & $\mathrm{R}$ & $\mathrm{SD}$ & 6 か月 \\
8 & 生検のみ & - & 6 か月 \\
9 & 生検のみ & - & 2 か月 \\
10 & $\mathrm{O}$ (減量 $)$ & 腫瘍増大なし & 2 か月 \\
11 & 生検のみ & - & 3 か月 \\
\hline $\mathrm{C}:$ 化学療法 & $\mathrm{R}:$ 放射線療法 & $\mathrm{O}:$ 手術療法 \\
$\mathrm{SD}:$ Stable Disease & $\mathrm{PD}:$ Progressive Disease
\end{tabular}

\section{再来時現症：}

全身所見; 接触痛のため食事䝮取が困難で，体重は 1 か月 間で $8 \mathrm{~kg}$ 減少していた。倦急感が強く, Eastern Cooperative Oncology Group の Performance Status では Score 3 であっ た.
口腔外所見；頭頂部，前頭部の皮下にそれぞれ径 $10 \mathrm{~mm}$, $20 \mathrm{~mm}$ の腫瘤を認め, 両側䫈下リンパ節の腫大も認めた. 右側オトガイ神経領域の知覚鈍麻は持続していた。

口腔内所見; 右側下顎臼後部に $50 \times 25 \mathrm{~mm}$ 大の弾性硬 の腫瘤を認めた。表面は潰瘍状を呈し, 易出血性で強い接 触痛を認めた (写真 1$)$.

画像所見：CT で右側下顎臼菊部の下顎骨内を中心とす る腫瘤形成と骨破壊を認めた (写真 2 ). 胸部単純 $\mathrm{X}$ 線写真 で両肺に複数の結節性陰影を認めた。

血液学的所見：AST: 45 IU/L, ALP: 318 IU/L, LDH: 569 IU/L と上昇を認めた。その他に異常值は認めなった.

臨床診断：口腔癌または他臓器からの転移性腫瘍.

処置および経過 2：口腔内病変の生検の結果 (写真 $3 \mathrm{~A})$, 消化管由来の腺癌の可能性が高いと診断されたため, FDGPET 検査を施行したところ, 全身に多発する集積像を認め た (写真 4A) 。とくに強い集積像（写真 4B）を認めた下部 消化管の内視鏡検査と生検の結果 (写真 $3 B$ ) から, S 状結 腸を原発とする進行性大腸癌 (Stage IV) と診断された。当 院腫瘍内科, 消化器外科を受診し, 原発腫瘍と全身の多発 転移巣については根治的な治療は困難であり, 延命のため の化学療法や姑息的な外科療法, 放射線療法も患者の全身 状態から適応外と診断された。口腔病変についても, 全身 状態抢よび腫瘍の進行度から, 治療による QOL の改善効 果が低いと判断し，2 月下旬に緩和ケアを専門とする施設 へ転院した。 3 月下旬に呼吸不全により死亡した。 


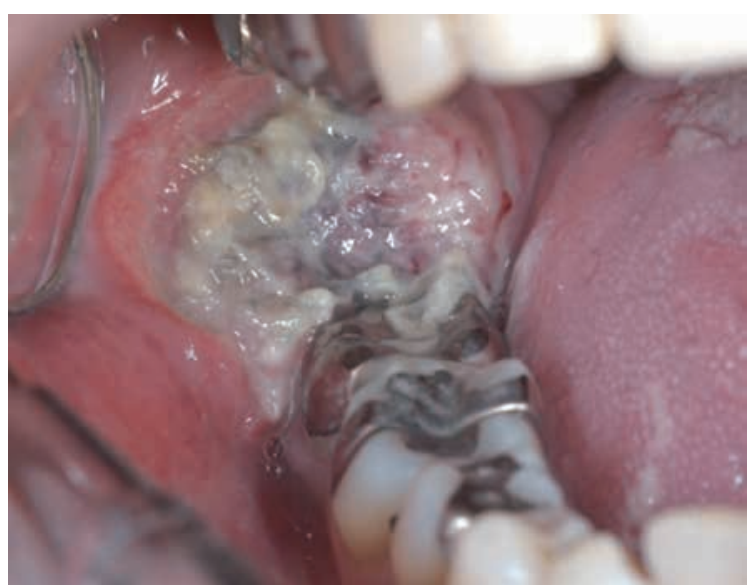

写真 1 症例 11 の口腔内写真

右側下顎巨後部菊肉に表面潰瘍状で周囲に硬結を 伴う腫瘤を認める.

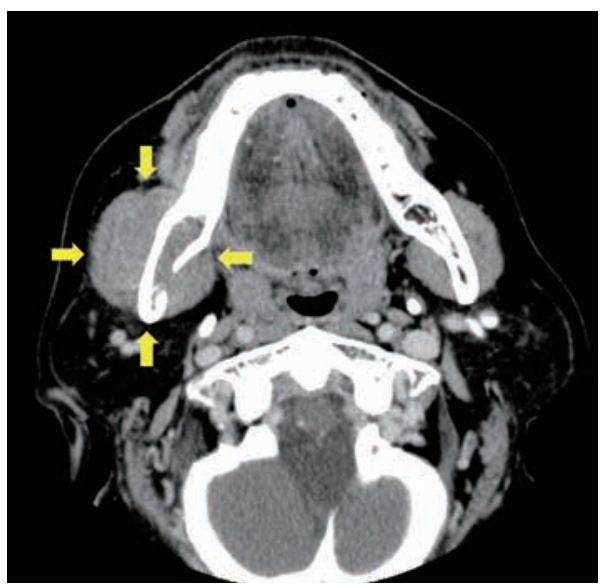

写真 2 症例 11 の CT 画像

右側下顎臼㐘部相当部の顎骨内を中心とする腫瘤 形成と骨破壊（矢印）を認める.
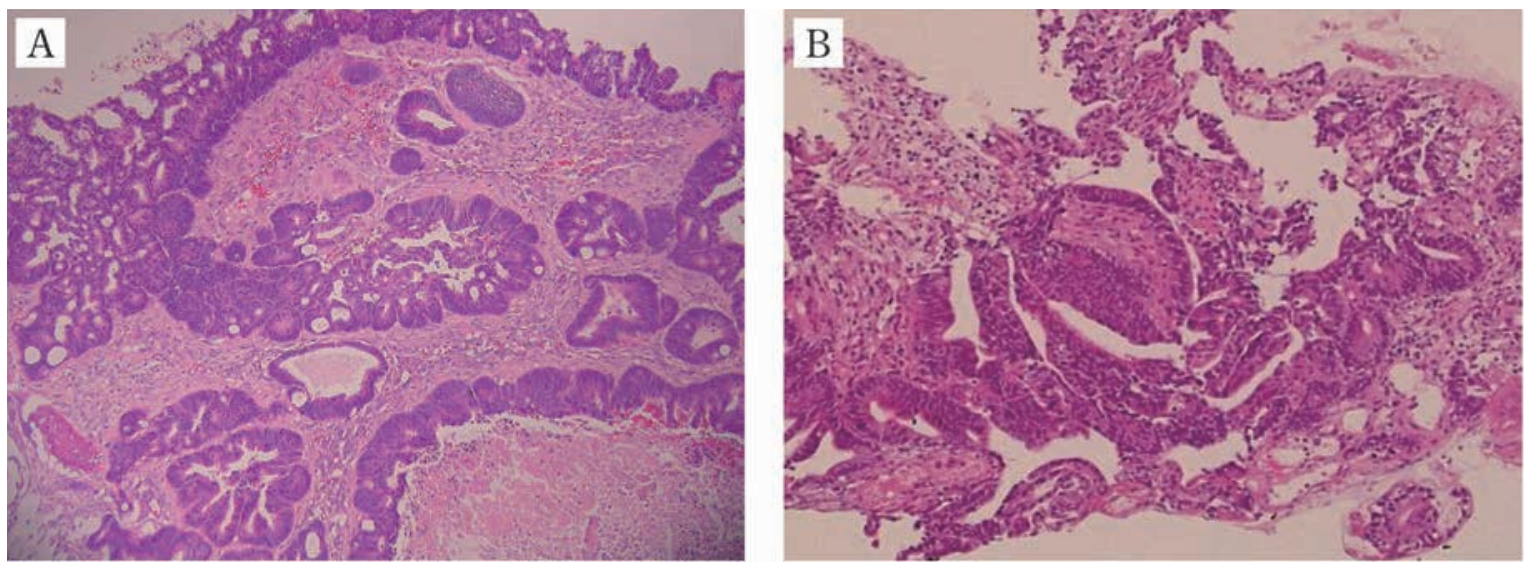

写真 3 症例 11 の病理組織像 (HE)

$\mathrm{A}$ ：口腔転移巣 $(\times 40) \quad$ B : 大腸原発巣 $(\times 40)$

$\mathrm{A}, \mathrm{B}$ ともに異型円柱状細胞が形態不整な管腔構造を形成している.
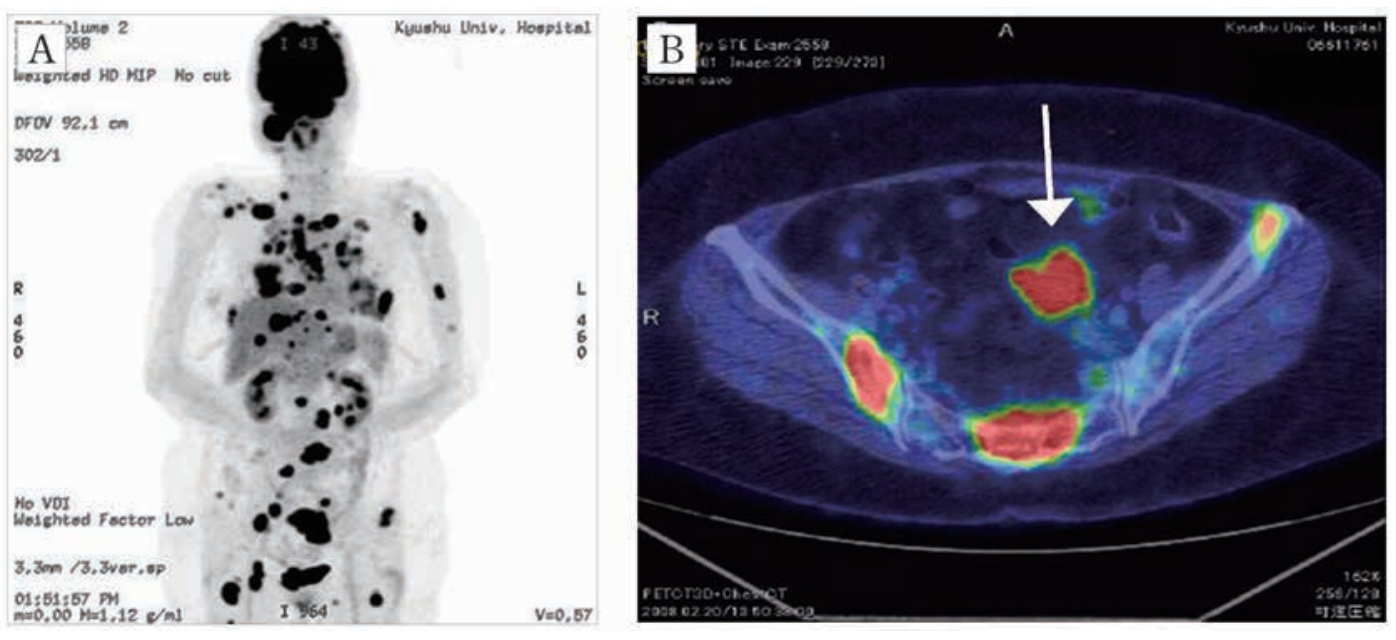

写真 4 症例 11 の FDG-PET 像

$\mathrm{A}$ ：全身に多発する FDG 集積像. B : S 状結腸の FDG 集積部 (矢印). 


\section{考}

1985 年から 2010 年に九州大学病院顔面口腔外科を受診 し, 病理組織学的に顎口腔領域への転移性悪性腫瘍と診断 された 11 例の頻度は，過去の報告 ${ }^{1,2}$ ) と同程度で全口腔 悪性腫瘍の $1.6 \%$ あったた。しかし，転移性腫瘍では進行 症例が多く，患者の年齢や全身状態を考慮し病理組織学的 検索を行い得ない場合も少なくないと考えられる。事実， 剖検例でのその頻度は $11.7 \%$ という報告 ${ }^{3)}$ があることか ら，転移性腫瘍は必ずしもまれではなく，顎口腔領域の悪 性腫瘍の診断に際して考慮すべき病態と考えられる.

発症年齢や性差については特定の傾向はないとの報告が 多く4,9)，私たちの検討でも同様であった．顎口腔領域へ の転移性悪性腫瘍の原発部位に関しては，海外では，男性 は肺, 腎, 肝, 前立腺, 女性は乳腺, 女性生殖器, 腎, 大腸 の順で多いという報告があり ${ }^{4)}$ ，本邦では男女別のデータ はないが, 肺, 子宮, 腎の順に多いと報告されている ${ }^{7,10)}$. これらは悪性腫瘍の藏器別の発生頻度 ${ }^{11)}$ と概ね同様の傾 向ではあるが, 口腔への転移では肺癌, 腎癌が比較的頻度 が高く, 大腸癌は少ない傾向がある ${ }^{4,7,10,12 \sim 14)}$. 当科の 症例でも肺，胃，子宮からの転移例が複数あった。一方， 心臓の悪性腫瘍の口腔転移は渉絾し得た限り過去に報告が なかった。このように原発腫瘍も多様であり，悪性腫瘍の 既往のある患者においては，口腔癌の診断時に転移性腫瘍 の可能性も考慮する必要があると思われた。

顎口腔領域への転移時には既に他藏器にも転移している ことが多い． $25 \%$ 症例に打いて，顎口腔領域への転移発 見後に他臓器の転移巣や非制御の原発巣の発見に至ったと いう報告がある ${ }^{4)}$ 。今回の 11 例でも，3 例は原発腫瘍の 治療効果が良好であった症例に生じたものであり，2 例は 顎口腔領域の転移が初発症状であった。

今回の症例では 11 例中 9 例に腫瘤形成を認め，そのうち 7 例は境界明瞭で表面平滑な長径 $30 \mathrm{~mm}$ を超える大きな腫 瘤を形成した。これは口腔癌の多くを占める扁平上皮癌が 少なく, 腺癌が 7 例を占めるという組織学的な要因と, 潰 瘍形成や患部の自発痛を伴うことが比較的少ないため，患 者も医療従事者も病変に気付かず，腫瘤が増大してから受 診している状況によるものと考えられた。さらに腫瘤を形 成した 9 例は同時に骨吸収像を認めていたため, 片岡ら 7 ) の分類で骨転移としたが，それら以外の 2 例も下顎の病変 で，知覚鈍麻が認められたことから骨転移とした。一般的 に顎骨と軟組織への転移の割合は $2: 1$ 程度で ${ }^{4)}$ ，顎骨で は臼菊部への転移が多く $\left.{ }^{3,4}, 7,10\right) ， 80 \%$ 以上が下顎への転 移と報告されている ${ }^{4)}$ 。一方，軟組織では付着柬肉への転 移が $54 \%$ と最も多く, 次いで舌, 煩粘膜, 口唇の順とさ れる ${ }^{4)}$. 今回の 11 例はすべて顎骨への転移症例で，その うち 9 例は下顎骨への転移であった。顎関節部へ転移した
1 例以外の上顎 2 例，下顎 8 例は臼柬部への転移であり， 過去の報告 ${ }^{4,7}$ ) と同様の結果であった.

下顎骨への腫瘍浸潤に伴うオトガイ神経領域の知覚鈍麻 （いわゆる numb chin syndrome）が，下㖽臼菊部へ転移し た 9 例中，上述の 2 例を含む 5 例で認められたが，これも 転移性悪性腫瘍の診断における重要な所見とされている ${ }^{7}$ 15〜17). 今回提示した症例 11 では口腔領域の症状は知覚 鈍麻のみで，悪性腫瘍の既往が初診時には明らかでなかっ た。そのため，診断の過程で早期に転移性腫瘍の可能性を 考慮するに至らなかったことは反省すべき点である。他臓 器の悪性腫瘍の既往の有無に係わらず，原因疾患の明らか でない知覚鈍麻に対しては，転移性腫瘍も念頭に入れて精 査，観察を行う必要があると考えられた。

顎口腔領域への転移性腫瘍は認知度が低く，エプーリ ス，歯周炎や骨髄炎等の炎症性疾患と臨床所見が類似して いる場合も多い. とくに近年悪性腫瘍の骨転移に対するビ スフォスフォネート製剤や分子標的薬の使用が増加してい るが，その副作用としての䫈骨壊死と転移性腫瘍とは共通 する既往を有する病態であり，注意深く鑑別する必要があ る。今回の症例では, 症例 2 のみビスフォスフォネート製 凨の内服薬が投与されていた。明らかな腫瘤形成を認めた ため腫瘍性疾患を第一に考慮したが，腫瘤を形成しない症 例では，知覚鈍麻など両者が同様の臨床症状を呈する可能 性も考えられる。抜㐘や消炎を目的とした切開等の処置が 行われていた症例もあるが，転移性腫瘍の臨床的な特徴を 踏まえ対応を検討する必要があると考えられた。

原発腫瘍の診断時点から顎口腔領域の転移までの期間 は平均 40 か月，転移の診断からの平均余命は 7 か月と報 告されている ${ }^{4)}$. 今回の症例では前者は 1 か月から 72 か 月 (平均 19.3 か月), 後者は 1 か月から 6 か月 (平均 3.2 か 月）と，経過はきわめて不良であった。骨への転移性腫瘍 における根治的治療の適応として, 阿部ら ${ }^{18)}$ は全身状態 が良好であること，原発巣が制御されていること，転移巣 が単発性であることなどを挙げている。しかし，顎口腔領 域の転移性悪性腫瘍では, 判明した時点で他藏器にも転移 をきたしている症例が多く，根治的治療が困難であるた め, 多くの場合 QOLの維持が治療の目標とならざるを得 ない。口腔は損食や会話等の重要な機能を有し, 形態的に も QOL に直結する器官であるため, 腫瘍の増殖速度, 放 射線療法および化学療法に対する感受性など, 腫瘍の特徴 と全身状態を十分考慮した上で個々に治療方針を決定し， 最善の支持療法を行うことが重要と考えられた。

\section{結語}

顎口腔領域への転移性腫瘍の臨床的特徴について文献的 考察を加え報告した。 
謝辞

稿を終えるにあたり，本研究に多大なるご協力とご指導を賜 りました九州大学大学院菊学研究院口腔顎顔面病態学講座口腔 顎顔面外科学分野の元准教授 竹之下康治先生に深謝申し上げ ます。

本論文に関して，開示すべき利益相反状態はない。

\section{引用文献}

1) Meyer I and Shklar G : Malignant tumors metastatic to mouth and jaws. Oral Surg Oral Med Oral Pathol 20: 350-362, 1965.

2 ）坂下英明, 宮田 勝, 他：口腔扎よび頸部への転移 性癌の 3 例. 口科誌 39: 90-98, 1990.

3 ) 井口裕一, 井上 孝, 他：下顎骨に打ける転移性腫 瘍の 2 症例. 日口外誌 29: 83-90, 1983.

4 ) Hirshberg A, Shnaiderman-Shapiro A, et al : Metastatic tumours to the oral cavity-Pathogenesis and analysis of 673 cases. Oral Oncol 44: 743-752, 2008.

5 ) Clausen F and Paulsen H : Metastatic carcinoma of the jaws. Acta Pathol Microbiol Scand 57: 361-374, 1963.

6 ) Zegarelli DJ, Tsukada Y, et al : Metastatic tumor to the tongue. Report of twelve cases. Oral Surg Oral Med Oral Pathol 35: 202-211, 1973.

7 ) 片岡 聡, 柴田昌美, 他：口腔転移性悪性腫瘍 17 例 の臨床的検討. 日口外誌 49: 566-569, 2003.

8 ) Sugiyama G, Ohyama Y, et al : Metastatic adenocarcinoma of the mandibular condyle from uterine cervix:
Report of a case. Oral Sci Int 11: 40-43, 2014.

9 ) D' Silva NJ, Summerlin DJ, et al : Metastatic tumors in the jaws: a retrospective study of 114 cases. J Am Dent Assoc 137: 1667-1672, 2006.

10）赤坂庸子, 神部芳則, 他：口腔への転移癌に関する 臨床的検討. 日口外誌 47: 559-562, 2001.

11) Matsuda A, Matsuda $T$, et al : Cancer incidence and incidence rates in Japan in 2007: a study of $21 \mathrm{Popu}-$ lation-based cancer registries for the Monitoring of Cancer Incidence in Japan (MCIJ) project. Jpn J Clin Oncol 43: 328-336, 2013.

12) 井口広義, 和田匡史, 他 : 胸腹部臟器から頭頸部領 域への遠隔転移癌. 頭頸部癌 35: 416-420, 2009.

13) Maschino F, Guillet J, et al : Oral Metastasis: a report of 23 cases. Int J Oral Maxillofac Surg 42: 164-168, 2013.

14) Murillo J, Bagan JV, et al : Tumors Metastasizing to the Oral Cavity: A Study of 16 Cases. J Oral Maxillofac Surg 71: 1545-1551, 2013.

15) Glaser C, Lang S, et al : Clinical manifestations and diagnostic approach to metastatic cancer of the mandible. Int J Oral Maxillofac Surg 26: 365-368, 1997.

16）中川清昌, 熊谷茂宏, 他：口腔内転移をきたした肺 癌の 3 例. 日口外誌 37: 1363-1371, 1991.

17）莇生田整治, 高森康次, 他：嚬口腔領域転移性腫瘍 13 例の臨床的検討. 口腔腫瘍 21: 255-264, 2009.

18）阿部光俊, 真鍋昌平, 他：転移性腫瘍 転移のメ力 ニズムと診断・治療, 問題点. 最新医学 41: 23712378, 1986. 